\title{
Quantitative evaluation of the progressive wear of powered interproximal reduction systems after repeated use
}

\author{
An in vitro study \\ C. Livas ${ }^{1,2} \cdot$ T. Baumann 3 - S. Flury ${ }^{3}$ N. Pandis ${ }^{2}$ \\ Received: 27 March 2019 / Accepted: 31 August 2019 / Published online: 13 November 2019
}

(c) The Author(s) 2019

\begin{abstract}
Purpose To evaluate the residual surface roughness of 5 common diamond-coated interproximal reduction (IPR) systems after consecutive in vitro applications in relation to system, diamond grain size, and instrument thickness.

Methods IPR was performed on 80 extracted human incisors using motor-driven strips and discs under predefined conditions. The IPR auxiliaries were applied at 5 consecutive sessions of $20 \mathrm{~s}$ on intact interproximal surfaces, and the surface profile $\left(R_{a}, R_{z}, R_{\max }\right)$ was analyzed at baseline and after each session with an optical profilometer.

Results No overall significant difference in the roughness values was found between systems $\left(P=0.07\right.$ for $\mathrm{R}_{\mathrm{a}}, P=0.33$ for $\mathrm{R}_{\mathrm{z}}$, and $P=0.48$ for $\mathrm{R}_{\max }$ ). There was a significant average decrease of $\mathrm{R}_{\mathrm{a}}, \mathrm{R}_{\mathrm{z}}$, and $\mathrm{R}_{\max }$ for all systems for every unit increase in time by $-0.171 \mu \mathrm{m}(P<0.001),-3.297(P \leq 0.001)$, and $-2.788 \mu \mathrm{m}(P=0.001)$, respectively. $\mathrm{R}_{\mathrm{a}}, \mathrm{R}_{\mathrm{z}}$, and $\mathrm{R}_{\mathrm{max}}$ values increased significantly, i.e., by $0.194 \mu \mathrm{m}(P=0.003), 5.890 \mu \mathrm{m}(P=0.001)$, and $5.319 \mu \mathrm{m}(P=0.010)$ as instrument thickness increased by one unit. No significant reductions in $R_{a}, R_{z}$, and $R_{\max }$ were observed across grain sizes $(-0.008 \mu \mathrm{m}$ $[P>0.05],-0.244 \mu \mathrm{m}[P>0.05]$, and $-0.179 \mu \mathrm{m}[P>0.05]$, respectively). There was no evidence of interaction between system and time as the $P$ values for $\mathrm{R}_{\mathrm{a}}, \mathrm{R}_{\mathrm{z}}$, and $\mathrm{R}_{\max }$ were $0.88,0.51$, and 0.70 , respectively.

Conclusions All IPR materials presented significant gradual decrease of surface roughness after repeated applications. There were no significant roughness changes among auxiliaries of different grain sizes. Thinner auxiliaries showed significantly more roughness reduction, possibly requiring more frequent replacement than thick auxiliaries in clinical practice.
\end{abstract}

Keywords Dental high-speed technique $\cdot$ Surface roughness $\cdot$ Optical profilometer $\cdot$ Dental enamel $\cdot$ Enamel stripping methods

\section{Quantitative Untersuchung der fortschreitenden Abnutzung elektrisch angetriebener Interproximal-Reduktionssysteme bei wiederholter Anwendung}

Eine In-vitro-Studie

\section{Zusammenfassung}

Ziel Beurteilt werden sollte die verbleibende Oberflächenrauigkeit von 5 handelsüblichen diamantbeschichteten Interproximal-Reduktionssystemen nach wiederholter In-vitro-Anwendung, differenziert wurde dabei bezüglich System, Diamantkorngröße und Instrumentendicke.

C. Livas

c.livas@acta.nl

1 Department of Orthodontics, Academic Centre for Dentistry Amsterdam (ACTA), University of Amsterdam and VU University Amsterdam, Gustav Mahlerlaan 3004, 1081 LA Amsterdam, The Netherlands
2 Department of Orthodontics and Dentofacial Orthopedics, Dental School/Medical Faculty, University of Bern, Freiburgstraße 7, 3010 Bern, Switzerland

3 Department of Restorative, Preventive and Pediatric Dentistry, Dental School/Medical Faculty, University of Bern, Freiburgstraße 7, 3010 Bern, Switzerland 
Methoden Interproximal-Reduktion (IPR) wurde mit motorgetriebenen Streifen oder Scheiben an 80 extrahierten menschlichen Inzisiven unter standardisierten Bedingungen durchgeführt. Die IPR-Systeme wurden für 5 aufeinander folgende Anwendungen von $20 \mathrm{~s}$ an intakten Interproximalflächen eingesetzt, die Oberflächenrauigkeit $\left(R_{a}, R_{z}, R_{\max }\right)$ wurde sowohl initial als auch nach jeder Anwendung mit einem optischen Profilometer analysiert.

Resultate Es wurden keine signifikanten Unterschiede der Oberflächenrauigkeit zwischen den unterschiedlichen Systemen festgestellt ( $p=0,07$ für $\mathbf{R}_{\mathrm{a}}, p=0,33$ für $\mathbf{R}_{\mathrm{z}}, p=0,48$ für $\mathbf{R}_{\mathrm{max}}$ ). Eine signifikante durchschnittliche Abnahme von $\mathbf{R}_{\mathrm{a}}, \mathbf{R}_{\mathrm{z}}$ und $\mathrm{R}_{\max }$ von $-0,171 \mu \mathrm{m}(p<0,001),-3,297 \mu \mathrm{m}(p \leq 0,001)$ bzw. $-2,788 \mu \mathrm{m}(p=0,001)$ nach jeder Anwendung wurde

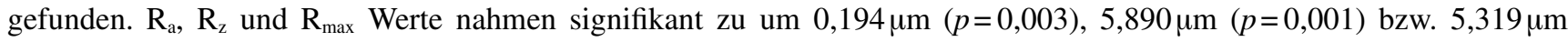
$(p=0,010)$ bei zunehmender Instrumentendicke pro Einheit. Bezüglich der Diamantkorngrößen wurden keine signifikanten Unterschiede von $\mathrm{R}_{\mathrm{a}}, \mathrm{R}_{\mathrm{z}}$ und $\mathrm{R}_{\max }(-0,008 \mu \mathrm{m}[p>0,05],-0,244 \mu \mathrm{m}[p>0,05]$ bzw. $-0,179 \mu \mathrm{m}[p>0,05])$ gefunden. Es gab keine Anzeichen für eine Interaktion zwischen Systemtyp und Anwendungsanzahl für $\mathbf{R}_{\mathrm{a}}, \mathbf{R}_{\mathrm{z}}$ und $\mathbf{R}_{\max }$, mit $p$-Werten von $0,88,0,51$ bzw. 0,70 .

Schlussfolgerungen Alle IPR-Systeme zeigten eine signifikante graduelle Abnahme der Oberflächenrauigkeit nach wiederholten Anwendungen. Es gab keine signifikanten Rauigkeitsdifferenzen zwischen Instrumenten mit unterschiedlichen Diamantkorngrößen. Bei dünneren Instrumenten gab es signifikant höhere Rauigkeitsverluste, was möglicherweise in der Praxis einen häufigeren Wechsel als bei dickeren Instrumenten nötig macht.

Schlüsselwörter Zahnmedizinische Hochgeschwindigkeitstechnik · Oberflächenrauigkeit · Optische Profilometrie · Zahnschmelz $\cdot$ Methoden zur Schmelzreduktion

\section{Introduction}

Space gaining procedures, e.g., tooth extractions, arch expansion, and reshaping of interproximal enamel surfaces (i.e., interproximal reduction [IPR]) are commonly applied in clinical orthodontics. Since the original introduction of IPR [1], several authors [2-6] have described in detail IPR indications and protocols for handheld or handpiecemounted enamel cutting instruments. Overall, IPR has been used to address arch length discrepancies, to enhance anterior esthetics and interocclusal relationships, and to improve long-term stability of the treatment outcome [7].

The residual enamel roughness [8-10], and especially, the increased susceptibility to caries in vitro [11-13] initially discouraged clinicians from performing IPR in everyday practice. This perception has been drastically changed in recent years with the best available evidence indicating that IPR does not increase the incidence of caries on treated teeth [14]. Moreover, regardless of the stripping method used (i.e., abrasive strips, tungsten carbide burs or oscillating perforated diamond discs), finishing with Sof-Lex polishing discs can yield smoother surfaces than intact enamel [15].

While most of the research focused on post-IPR enamel effects, very little has been published so far on the wear of IPR materials after multiple uses [16]. Such information may have direct clinical implications since the particle size of the abrasive determines the amount of enamel reduction as well as the necessary time for polishing [17]. Lione et al. [16] demonstrated by means of tribological testing a $60 \%$ decrease in the abrasive capacity of motor-driven strips after $5 \mathrm{~min}$ of in vitro use, whereas at the same time almost complete detachment of diamond abrasive grains was observed by scanning electron microscope in three patients receiving IPR on mandibular incisors.

Given the growing acceptance of IPR as a minimally invasive procedure by dentists and orthodontists [18], and the widespread use of aligner treatment in combination with IPR [19], it would be interesting from a clinical point of view to investigate the surface changes on contemporary IPR materials over time. Thus, the aims of this study are to assess the roughness changes of 5 popular diamond-coated IPR systems after consecutive in vitro applications in relation to system, diamond grain size, and instrument thickness. The null hypothesis is that there is no difference in the outcome between any of the parameters.

\section{Materials and methods}

Eighty extracted human permanent incisors with macroscopically intact interproximal surfaces, free of caries and restorations were collected from the undergraduate clinic of the Department of Preventive, Restorative, and Pediatric Dentistry, Dental School/Medical Faculty, University of Bern, Bern, Switzerland. Before extraction, patients had been informed about the use of the teeth for research purposes and verbal consent had been obtained. After extraction, the teeth were pooled. The local ethics committee categorizes pooled teeth as an "irreversibly anonymized biobank" and thus, no previous ethical approval was needed. The incisors to be used were cleaned under tap water with a scaler to remove debris and then stored in $2 \%$ chloramine solution in a refrigerator $\left(4^{\circ} \mathrm{C}\right)$ until needed. The incisors 
Table 1 Technical details of the interproximal reduction (IPR) instruments tested in the study

Tab. 1 Technische Details der getesteten IPR(Interproximal-Reduktion)-Systeme

\begin{tabular}{|c|c|c|c|c|c|c|}
\hline System & Manufacturer & Instrument coding & $\begin{array}{l}\text { Thickness } \\
(\mathrm{mm})\end{array}$ & $\begin{array}{l}\text { Particle size } \\
(\mu \mathrm{m})\end{array}$ & Handpiece & Manufacturer \\
\hline \multirow{3}{*}{$\begin{array}{l}\text { DentaSonic } \\
\text { Diastrip }\end{array}$} & \multirow{3}{*}{$\begin{array}{l}\text { Alpin } \\
\text { Orthodontics, } \\
\text { Lucerne, } \\
\text { Switzerland }\end{array}$} & DS-25 & 0.15 & 25 & \multirow{3}{*}{$\begin{array}{l}\text { DentaSonic water } \\
\text { cooling HP }\end{array}$} & \multirow{3}{*}{$\begin{array}{l}\text { Alpin Orthodontics, } \\
\text { Lucerne, Switzerland }\end{array}$} \\
\hline & & DS-40 & 0.20 & 40 & & \\
\hline & & DS-60 & 0.30 & 60 & & \\
\hline \multirow{3}{*}{$\begin{array}{l}\text { Ortho-Strips } \\
\text { System }\end{array}$} & Intensiv SA, & OS-25 & 0.15 & 25 & \multirow{3}{*}{$\begin{array}{l}\text { Intensiv Swingle } \\
\text { Reciprocating } \\
\text { Contra Angle } \\
\text { (WG-69A) }\end{array}$} & \multirow[t]{3}{*}{ W\&H, Búrnmoos, Austria } \\
\hline & Montagnola, & OS-40 & 0.20 & 40 & & \\
\hline & & OS-60 & 0.25 & 60 & & \\
\hline \multirow[t]{3}{*}{ SDC-G5-Prostrip } & SDC & SDC-15 & 0.15 & 15 & Ti-Max X55 & \multirow{3}{*}{$\begin{array}{l}\text { NSK-Nakanishi Inc., } \\
\text { Kanuma, Japan }\end{array}$} \\
\hline & Switzerland & SDC-20 & 0.20 & 30 & & \\
\hline & $\begin{array}{l}\text { SA, B1ogg1o, } \\
\text { Switzerland }\end{array}$ & SDC-30 & 0.30 & 40 & & \\
\hline \multirow{4}{*}{$\begin{array}{l}\text { Galaxy IPR } \\
\text { Diamond Discs }\end{array}$} & Ortho & OT-11 & 0.19 & 64 & \multirow{4}{*}{$\begin{array}{l}\text { KaVo } \\
\text { GENTLE-power } \\
\text { LUX 10LP } \\
\text { Straight } 1: 2\end{array}$} & \multirow{4}{*}{$\begin{array}{l}\text { KaVo Dental, Charlotte, } \\
\text { NC, USA }\end{array}$} \\
\hline & Technology ${ }^{\circledR}$, & OT-13 & 0.19 & 64 & & \\
\hline & Lutz, FL, USA & OT-55 & 0.20 & 46 & & \\
\hline & & OT-56 & 0.20 & 46 & & \\
\hline \multirow{3}{*}{$\begin{array}{l}\text { OS Segment } \\
\text { Discs }\end{array}$} & \multirow{3}{*}{$\begin{array}{l}\text { Komet USA, } \\
\text { Rock Hill, SC, } \\
\text { USA }\end{array}$} & OS-10 & 0.20 & 57 & \multirow[t]{3}{*}{ Komet OS 31} & \multirow[t]{3}{*}{ W\&H, Bürnmoos, Austria } \\
\hline & & OS-20 & 0.20 & 25 & & \\
\hline & & OS-18 & 0.18 & 49 & & \\
\hline
\end{tabular}

were then mounted in cylindrical stainless steel molds with self-curing acrylic resin (Paladur, Heraeus Kulzer, Hanau, Germany). After curing of the acrylic resin, the stainless steel molds were removed and the embedded incisors were stored in the refrigerator at $100 \%$ humidity. For the IPR procedures, the embedded incisors were then randomly allocated to 16 groups of 5 teeth each.

\section{IPR procedures}

Five IPR systems, namely 16 instruments, were considered for the purposes of the study: DiaStrip (DentaSonic, Cham, Switzerland), Intensiv Ortho-Strips System (Intensiv SA, Montagnola, Switzerland), G5-ProLign (SDC Switzerland SA, Bioggio, Switzerland), Galaxy IPR Diamond Discs (Ortho Technology ${ }^{\circledR}$, Lutz, FL, USA), and OS Discs (Komet USA, Rock Hill, SC, USA). The technical characteristics of IPR auxiliaries are summarized in Table 1.

IPR was carried out by the same operator (first author) according to the manufacturers' recommendations. For Galaxy IPR Diamond Discs, the straight handpiece was operated at $5000 \mathrm{rpm}$; for the rest of the IPR systems, the contra-angle handpieces were operated at 40,000 rpm with water cooling. The tested auxiliaries underwent five consecutive IPR sessions on intact proximal surfaces. To reproduce the average clinical treatment time, IPR sessions were set at $20 \mathrm{~s}[20,21]$, reaching $100 \mathrm{~s}$ in total use for each auxiliary. After completion of IPR procedures, all systems were cleaned thoroughly with distilled water.

\section{Surface roughness evaluation}

The surfaces of IPR auxiliaries were analyzed with an optical profilometer (FRT MicroProf ${ }^{\circledR}$ 100, equipped with a H0 sensor, Fries Research \& Technology, Bergisch Gladbach, Germany). Linear traces were recorded at a pixel density of $1000 / \mathrm{mm}$. Due to the different forms of the instruments, different total lengths of the traces were obtained. For the DiaStrip system, the Intensiv Ortho-Strips system, and the G5ProLign system, the whole abrasive part could be measured. The resulting trace lengths were $13 \mathrm{~mm}$ (DiaStrip and Intensiv Ortho-Strips) and $17 \mathrm{~mm}$, respectively (G5-ProLign). The sector-shaped OS Discs were measured at the outer edges of the discs, where trace lengths of $5 \mathrm{~mm}$ could be obtained. For the disc shaped Galaxy IPR Diamond Discs, traces were measured radially from the outer edges toward the center. For three of the discs, namely OT-11, OT-13, and OT-55, radial traces through the whole abrasive part could be obtained in that way. The trace lengths were $2.7 \mathrm{~mm}$ (OT-11), $2.5 \mathrm{~mm}$ (OT-13), and 5.2 mm (OT-55). For the fourth disc, OT-56 containing a perforated surface, not the whole abrasive surface could be measured, as there was no radial linear path through it. We nevertheless obtained $3.7 \mathrm{~mm}$ long traces for this disc type. The average surface roughness $\left(\mathrm{R}_{\mathrm{a}}\right.$; in $\left.\mu \mathrm{m}\right)$, the maximum roughness depth $\left(\mathrm{R}_{\max }\right.$; in $\left.\mu \mathrm{m}\right)$, and the arithmetic mean height of the surface profile $\left(R_{z}\right.$; in $\left.\mu \mathrm{m}\right)$ where then determined for all the traces measured with a special software (Mark III, Fries Research \& Technology GmbH, Bergisch-Gladbach, Germany). Profilometric measurements were performed at baseline, i.e., before initiating IPR (T0), and after each ses- 
sion, i.e., at 20,40,60, 80, and $100 \mathrm{~s}$ (T1-T5) by a second examiner (third author), blinded to the experimental groups.

\section{Statistical analysis}

Random effects linear regression models were fitted using $R_{a}, R_{z}$, and $R_{\max }$ as the dependent variables respectively and system, grain size, thickness, and time. Interactions between system and time were also assessed. The level of statistical significance was set at $5 \%$. Statistical analysis was conducted with the Stata Statistical Software (Release 15, StataCorp LLC, College Station, TX, USA).

\section{Results}

The surface roughness values $\left(\mathrm{R}_{\mathrm{a}}, \mathrm{R}_{\mathrm{z}}, \mathrm{R}_{\max }\right)$ obtained by the optical profilometer are presented in Table 2. Surface roughness decreased with time across IPR system, thickness, and grain-size groups. No overall significance of system was found using likelihood ratio tests $\left(P=0.07\right.$ for $\mathrm{R}_{\mathrm{a}}, P=0.33$ for $\mathrm{R}_{\mathrm{L}}$, and $P=0.48$ for $\mathrm{R}_{\max }$ ).

There was a significant average decrease of $R_{a}, R_{z}$, and $\mathrm{R}_{\max }$ for all systems for every unit increase in time by $-0.171 \mu \mathrm{m}$ (95\% confidence interval [CI]: $-0.203,-0.139$; $P<0.001$ ),-3.297 (95\% CI: $-4.493,-2.100 ; P \leq 0.001$ ), and $-2.788 \mu \mathrm{m}(95 \% \mathrm{CI}:-4.422,-1.154 ; P=0.001)$, respectively (Table 3 ). $R_{\mathrm{a}}, \mathrm{R}_{\mathrm{z}}$, and $\mathrm{R}_{\max }$ values increased significantly, i.e., by $0.194 \mu \mathrm{m}$ (95\% CI: $0.068,0.321 ; P=0.003)$, $5.890 \mu \mathrm{m}(95 \%$ CI: $2.282,9.497, P=0.001)$, and $5.319 \mu \mathrm{m}$ (95\% CI: $1.258,9.379 ; P=0.010)$ as instrument thickness increased by one unit (Table 3 ). There was no significant average reduction of roughness values across grain sizes, viz. $-0.008 \mu \mathrm{m}$ (95\% CI: $-0.025,0.008 ; P>0.05),-0.244 \mu \mathrm{m}$ (95\% CI: $-0.709,0.221 ; P>0.05),-0.179 \mu \mathrm{m}(95 \% \mathrm{CI}$ : $-0.695,0.337 ; P>0.05$ ) (Table 3).

There was no evidence of interaction between system and time as the likelihood ratio tests $P$ values for $\mathrm{R}_{\mathrm{a}}, \mathrm{R}_{\mathrm{z}}$, and $R_{\max }$ were $0.88,0.51$, and 0.70 , respectively, and thus the interactions terms were dropped from the model. Roughness reduction by time, was comparable among systems (Fig. 1).

\section{Discussion}

As the popularity of IPR is increasing in nonextraction orthodontic treatment with fixed appliances and clear thermoplastic aligners, it is worthwhile to thoroughly explore the mechanical behavior of IPR systems. To the best of our knowledge, this is the first study designed to investigate the surface roughness changes in an extended list of commonly used handpiece-driven IPR instruments.
The lack of overall significance in roughness changes between systems indicates that no system was found superior to others in withstanding abrasive loss. All tested materials exhibited a significant reduction in surface roughness with time, which was comparable for all IPR systems. Given instrument surfaces were cleaned before each profilometric evaluation, it may be expected that in clinical conditions the decrease in roughness might be more rapid since besides detachment of diamond granules, increasing accumulation of tooth material on the instrument surface during the repeated applications might take place [16]. In addition, in daily practice, IPR is performed between adjacent teeth. In case proper contacts and mechanical access are not provided, forcing the stripping auxiliary into tight contact points and application of a heavy load by the clinician, will result in instrument deformation and a more rapid loss of abrasive power [16].

Thicker IPR auxiliaries showed significantly less abrasive wear compared to auxiliaries with thinner stripping segments. This finding implies that regardless of IPR system, thinner stripping instruments may require more frequent replacement when used in vivo. As other investigators stated, instrument thickness may influence the instrument deflection and achieved enamel reduction. The thicker or the more solid the IPR instrument, the more efficient the distribution of the applied force to the enamel surface [22].

Surface roughness of IPR systems was quantified in the present study by profilometry, a broadly used method for measuring the surface profile of dental materials [23-25]. Nevertheless, profilometry has been criticized for inducing sample damage and its inability to measure overall surface roughness due to scanning a single line in a preselected area $[26,27]$. By using a noncontact optical profilometer, we avoided any potential sample damage. Although the profilometer used would allow measurement of the roughness parameters for whole surfaces, the different kinds of perforations of the auxiliaries made it impossible to measure surfaces in a standardized way for all the auxiliaries. Therefore, we decided to rather measure traces of maximal lengths across the cross-sections of the abrasive parts of the auxiliaries. Furthermore, the optical profilometer provides an extremely high vertical resolution $(<10 \mathrm{~nm})$ and a set of roughness values that permits statistical analysis [28].

It is well-accepted that the amount of enamel reduction is influenced by operator- or technique-related aspects such as exerted pressure, hardness, and particle size of the abrasive, IPR duration, and tooth-related aspects such as enamel hardness [17]. As there is no data in the literature about the optimal applied force [22], to ensure standardization of the experimental IPR technique, enamel preparation was carried out by a single clinician within a predefined period, strictly following manufacturers' instructions for use. 


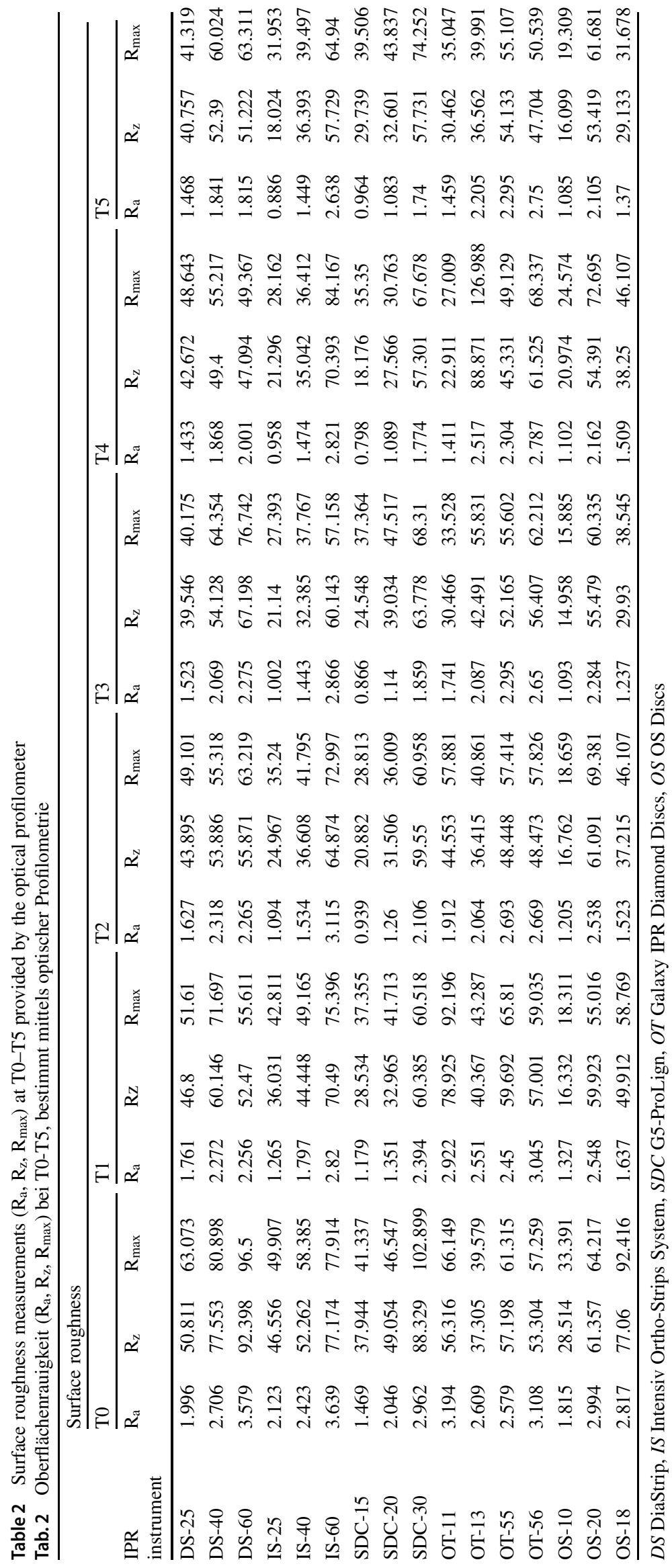




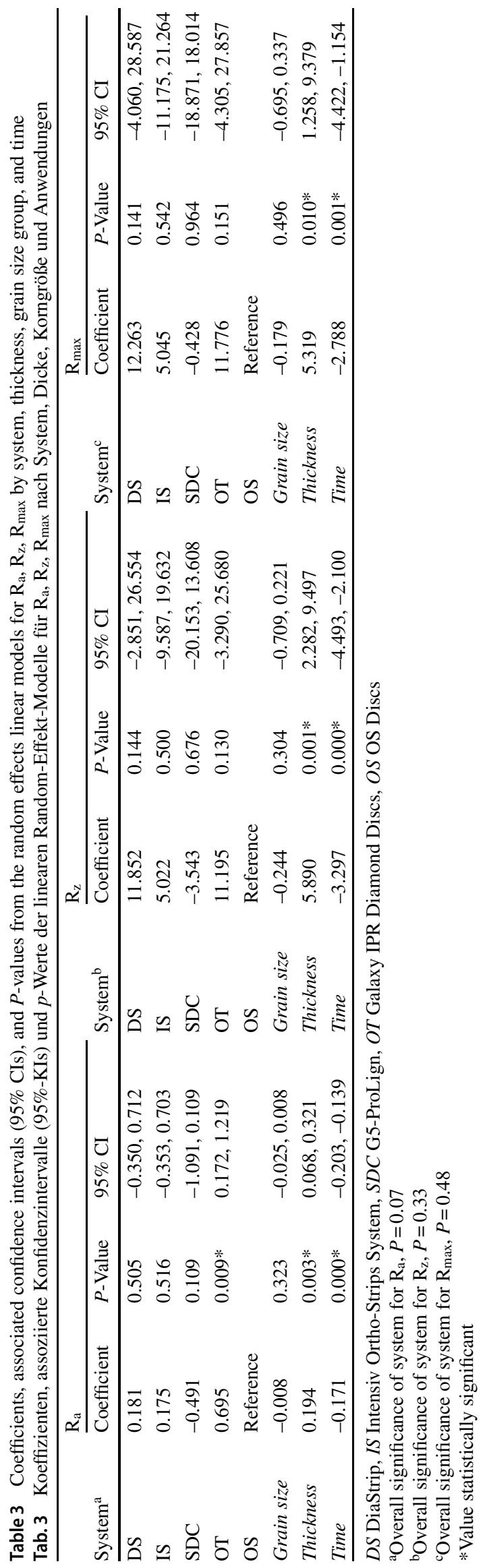

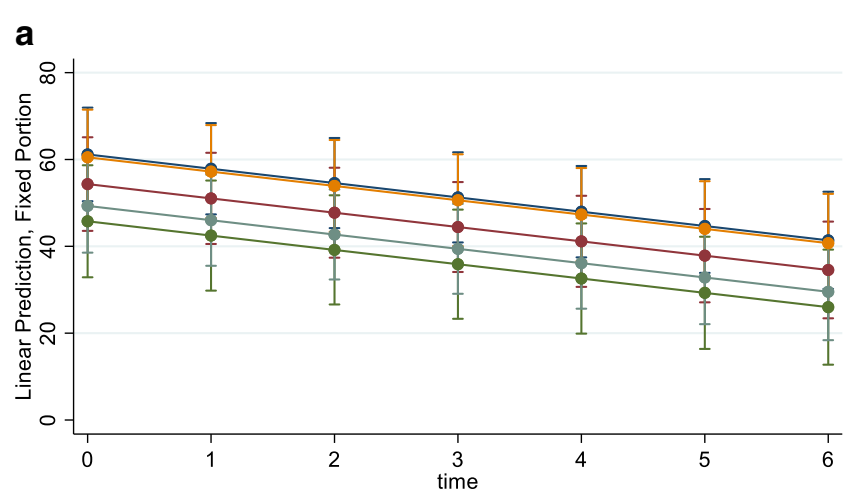
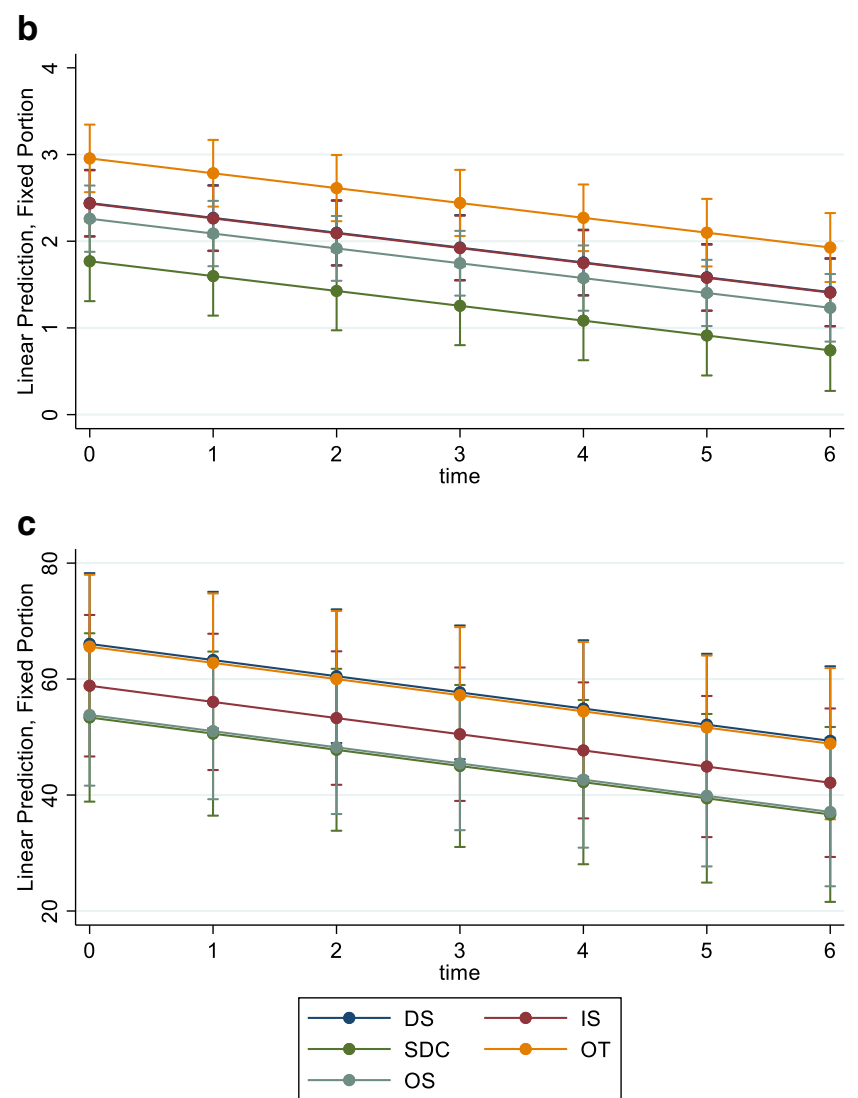

Fig. 1 Roughness changes of interproximal reduction (IPR) instruments in relation to time ( $\left(\mathbf{a} \mathrm{R}_{\mathrm{a}} ; \mathbf{b ~ R ~}_{\mathrm{z}} ; \mathbf{c} \mathrm{R}_{\max }\right)$. DS DiaStrip, IS Intensiv Ortho-Strips System, SDC G5-ProLign, OT Galaxy IPR Diamond Discs, OS OS Discs

Abb. 1 Veränderung der Oberflächenrauigkeit der IPR(InterproximalReduktion)-Systeme in Abhängigkeit der Anzahl Anwendungen (a $\mathrm{R}_{\mathrm{a}} ; \mathbf{b} \mathrm{R}_{\mathrm{z}}$; $\mathbf{c} \mathrm{R}_{\max }$ ). DS DiaStrip, IS Intensiv Ortho-Strips System, SDC G5-ProLign, OT Galaxy IPR Diamond Discs, OS OS Discs

Certain caveats need to be acknowledged when translating our study findings into clinical practice. The sample teeth were mounted in acrylic resin, and therefore, it may be presumed that no physiologic tooth movement during IPR was simulated. Alternative embedment in silicone, like in past studies [22, 29], has been criticized since silicone may fatigue faster that biological tissues. Possible loosening of 
the teeth in the silicone base could lead to insufficient resistance to the mechanical movement of the auxiliary, and eventually insufficient loading by the clinician during IPR [29]. Furthermore, during or after IPR in vivo, stretching of periodontal fibers might occur consequent to the initial aligning, causing tooth movement and underestimation of the stripping outcome [29]. Unlike clinical conditions, IPR in this in vitro investigation was carried out on individual teeth without the need for opening up the interproximal space. This was chosen deliberately to facilitate access to interproximal areas and direct study of surface roughness changes of IPR instruments after multiple applications.

Future studies should aim to evaluate the efficiency of powered IPR systems in vivo as well as user friendliness and patient comfort [22]. It would be useful to couple the abrasive wear of IPR auxiliaries with the actual amount of the stripped enamel, and to assess patient perception during IPR procedures with different systems. In this way, valuable recommendations can be made to clinicians about the lifecycle and frequency of replacement of IPR instruments to maximize treatment efficiency and patient comfort.

\section{Conclusions}

No system was found superior to others in withstanding abrasive wear. All tested powered stripping materials presented a significant decrease of surface roughness after repeated in vitro use. The grain size of the stripping segment did not have a significant effect on the observed roughness changes. Significantly less abrasive wear was observed in thicker auxiliaries, implying longer potential clinical use compared to thin IPR auxiliaries.

Acknowledgements This work was supported by Research Grant of the European Orthodontic Society awarded to the first author.

\section{Compliance with ethical guidelines}

Conflict of interest C. Livas, T. Baumann, S. Flury and N. Pandis declare that they have no competing interests.

Ethical standards The local ethics committee (Kantonale Ethikkommission, Bern, Switzerland; reference number: Req - 2016-00332) categorizes pooled teeth as an "irreversibly anonymized biobank" and thus, no previous ethical approval was needed.

Open Access This article is distributed under the terms of the Creative Commons Attribution 4.0 International License (http:// creativecommons.org/licenses/by/4.0/), which permits unrestricted use, distribution, and reproduction in any medium, provided you give appropriate credit to the original author(s) and the source, provide a link to the Creative Commons license, and indicate if changes were made.

\section{References}

1. Ballard ML (1944) Asymmetry in tooth size: a factor in the etiology, diagnosis, and treatment of malocclusion. Angle Orthod 14:67-71

2. Hudson AL (1956) A study of the effects of mesio-distal reduction of mandibular anterior teeth. Am J Orthod 42:615-624

3. Tuverson DL (1980) Anterior interocclusal relations. Part I. Am J Orthod 78:361-370

4. Sheridan JJ (1985) Air-rotor stripping. J Clin Orthod 19:43-59

5. Zhong M, Jost-Brinkmann PG, Zellmann M, Zellmann S, Radlanski RJ (2000) Clinical evaluation of a new technique for interdental enamel reduction. J Orofac Orthop 61:432-439

6. Zachrisson BU (2004) Interdental papilla reconstruction in adult orthodontics. World J Orthod 5:67-73

7. Ang AG, Steegmans PA, Kerdijk W, Livas C, Ren Y (2017) Radiographic technique and brackets affect measurements of proximal enamel thickness on mandibular incisors. Eur J Orthod 39:25-30

8. Joseph VP, Rossouw PE, Basson NJ (1992) Orthodontic microabrasive reproximation. Am J Orthod Dentofacial Orthop 102:351-359

9. Piaccentini C, Sfondrini G (1996) A scanning electron microscopy comparison of enamel polishing methods after air-rotor stripping. Am J Orthod Dentofacial Orthop 109:57-63

10. Arman A, Cehreli B, Ozel E, Arhun N, Cetinsahin A, Soyman M (2006) Qualitative and quantitative evaluation of enamel after various stripping methods. Am J Orthod Dentofacial Orthop 130:131.e7-131.e14

11. Zachrisson BU, Mjör IA (1975) Remodeling of teeth by grinding. Am J Orthod Dentofacial Orthop 68:545-553

12. Radlanski RJ, Jäger A, Schwestka R, Bertzbach F (1998) Plaque accumulation caused by interdental stripping. Am J Orthod Dentofacial Orthop 94:416-420

13. Twesme DA, Firestone AR, Heaven TJ, Feagin FF, Jacobson A (1994) Air-rotor stripping and enamel demineralization in vitro. Am J Orthod Dentofacial Orthop 105:142-152

14. Koretsi V, Chatzigianni A, Sidiropoulou S (2014) Enamel roughness and incidence of caries after interproximal enamel reduction: a systematic review. Orthod Craniofac Res 17:1-13

15. Livas C, Jongsma AC, Ren Y (2013) Enamel reduction techniques in orthodontics: a literature review. Open Dent J 7:146-151

16. Lione R, Gazzani F, Pavoni C, Guarino S, Tagliaferri V, Cozza P (2017) In vitro and in vivo evaluation of diamond-coated strips. Angle Orthod 87:455-459

17. Hein C, Jost-Brinkmann PG, Schillai G (1990) The enamel surface quality after interproximal stripping-a scanning electron microscopic assessment of different polishing procedures. Fortschr Kieferorthop 51:327-335

18. Barcoma E, Shroff B, Best AM, Shoff MC, Lindauer SJ (2015) Interproximal reduction of teeth: differences in perspective between orthodontists and dentists. Angle Orthod 85:820-825

19. Keim RG, Gottlieb E, Vogels DS 3rd, Vogels PB (2014) JCO study of orthodontic diagnosis and treatment procedures, Part 1: results and trends. J Clin Orthod 48:607-630

20. Danesh G, Hellak A, Lippold C, Ziebura T, Schafer E (2007) Enamel surfaces following interproximal enamel reduction with different methods. Angle Orthod 77:1004-1010

21. Hellak AF, Riepe EM, Seubert A, Korbmacher-Steiner HM (2015) Enamel demineralization after different methods of interproximal polishing. Clin Oral Investig 19:965-972

22. Zingler S, Sommer A, Sen S, Saure D, Langer J, Guillon O, Lux CJ (2016) Efficiency of powered systems for interproximal enamel reduction (IER) and enamel roughness before and after polishing-an in vitro study. Clin Oral Investig 20:933-942 
23. Flury S, Lussi A, Zimmerli B (2010) Performance of different polishing techniques for direct CAD/CAM ceramic restorations. Oper Dent 35:470-481

24. Flury S, Peutzfeldt A, Lussi A (2012) Influence of surface roughness on mechanical properties of two computer-aided design/ computer-aided manufacturing (CAD/CAM) ceramic materials. Oper Dent 37:617-624

25. Flury S, Diebold E, Peutzfeldt A, Lussi A (2017) Effect of artificial toothbrushing and water storage on the surface roughness and micromechanical properties of tooth-colored CAD-CAM materials. J Prosthet Dent 117:767-774

26. Miró MM, Veith M, Lee J, Soldera F, Mücklich F, Bennewitz R, Aktas C (2015) 3D and 2D structural characterization of 1D Al/Al2 O3 biphasic nanostructures. J Microsc 258:113-118
27. Rudge P, Sherriff M, Bister D (2015) A comparison of roughness parameters and friction coefficients of aesthetic archwires. Eur J Orthod 37:49-55

28. Lundgren T, Milleding P, Mohlin B, Nannmark U (1993) Restitution of enamel after interdental stripping. Swed Dent J 17:217-224

29. Johner AM, Pandis N, Dudic A, Kiliaridis S (2013) Quantitative comparison of 3 enamel-stripping devices in vitro: how precisely can we strip teeth? Am J Orthod Dentofacial Orthop 143:S168-S172 